\title{
The semantic structure of gratitude
}

\author{
Alexander V. Smirnov, Alyona G. Obolenskaya, Ravil A. Valiev ${ }^{*}$ \\ Psychology Institute, Ural State Pedagogical University, Ekaterinburg, Russia \\ *Corresponding author. E-mail: rw1973@mail.ru
}

In the modern social and economic environment of Russia, gratitude might be considered an ambiguous phenomenon. It can have different meaning for a person in different contexts and can manifest itself differently as well (that is, as an expression of sincere feelings or as an element of corruption). In this respect it is topical to investigate the system of meanings and relationships that define the semantic space of gratitude. The goal of the study was the investigation and description of the content and structure of the semantic space of the gratitude phenomenon as well as the determination of male, female, age, and ethnic peculiarities of the expression of gratitude. The objective was achieved by using the semantic differential designed by the authors to investigate attitudes toward gratitude. This investigation was carried out with the participation of 184 respondents (Russians, Tatars, Ukrainians, Jews) living in the Russian Federation, Belarus, Kazakhstan, Tajikistan, Israel, Australia, Canada, and the United Kingdom and identifying themselves as representatives of one of these nationalities. The structural components of gratitude were singled out by means of exploratory factor analysis of the empirical data from the designed semantic differential. Gender, age, and ethnic differences were differentiated by means of Student's $t$-test. Gratitude can be represented by material and nonmaterial forms as well as by actions in response to help given. The empirical data allowed us to design the ethnically nonspecified semantic structure of gratitude. During the elaboration of the differential, semantic universals of gratitude, which constitute its psychosemantic content, were distinguished. Peculiarities of attitudes toward gratitude by those in different age and gender groups were revealed. Differences in the degree of manifestation of components of the psychosemantic structure of gratitude related to ethnic characteristics were not discovered. The semantic universals of gratitude are grouped into the components of its semantic structure: intentional, relational, essential, and expressive. These structural elements are present in the representatives of all the nationalities who participated in the study. The men were more likely than the women to demonstrate the instrumental understanding of gratitude. The women were more likely than the men to reflect humanistic ideas of gratitude. The romantic and noble idea of gratitude was dominant in representatives of the younger generation (18-year-olds). The young adults (19-to-25-year-olds) tended to demonstrate social realism to a larger extent than respondents in the other age groups. In respondents who were 26-years-old and above, humanistic assessment and collectivist values with respect to gratitude significantly decreased.

Keywords: gratitude, culture, sociocultural environment, semantic space, economic environment 


\section{Introduction}

In the current geopolitical situation, when religion, nationality, and ethnocultural differences of peoples are used as fields and tools for inciting conflicts, the scientific community responds to these adverse but stable trends with an abundance of research. The leitmotif for the research is the aspiration to reveal the genesis, the content, and ways of minimizing ethnocultural, religious, and ethnic conflicts (Agaev, 2013; Erokhin, 2013; Perin, 2003; Ryazanov, 2014; Sampiev, 2010; Shiryakov, 2014; Tengizova, 2014). The specifics of national character and national culture as well as religious/confessional differences and ethnic characteristics are being studied (Bajer, 2014; Belyakova \& Grigoryan, 2010; Bryanskaya, 2011; Klimenko, 2011; Muchkaev, 2012; Nadya, 2011; Rakhmatullina, 1999; Ri, 2014). In this article the ethnically nonspecified semantic structure of gratitude as well as peculiarities of the views on gratitude in different age and gender groups are presented. A theoretical framework and practical tools for further research of the gratitude phenomenon are elaborated.

\section{The socioeconomic environment as a semantic space}

In anthropology, cultural studies, and social psychology, a subjective semantic space is considered to exist as a system of categories of individual consciousness by means of which a person evaluates and classifies various objects, concepts, and events. It is postulated that, being immersed in a cultural, information, socioeconomic, and political environment, a person creates a system of perception and understanding of the surrounding reality and attitudes toward it (Zhukova, 2010). Internal and external contexts of the system are differentiated. The internal context is defined as specific features of the person's individuality represented at all levels. This individuality is understood as a set of all of one's unique human characteristics as an individual and personality. The external context is viewed as a system of social, sociocultural, socioeconomic, spatial and temporal, political, and other characteristics of the environment in which a person lives. The internal and external contexts in their interaction perform the meaning-forming function of all human life at each level of psychic reflection (Zhukova, 2010) and define a person's behavior and activity on the basis of the principle of the unity of consciousness and activity (Serkin, 2008). As a result the study of everyday ideas about the phenomenon of gratitude under the current economic conditions by means of psychosemantic methods allows us to determine what kind of internal semantic space (system of significations) is formed with respect to gratitude and what kind of stimulating effect it (the system of significations) produces.

Further we will consider here the relationship between the concepts meaning and signification in the context of psychosemantic methods. One's attitude toward the world's objects, deep structures of subjective experience, is presented in the form of sense relations ("a phenomenon for me," "the meaning of the event for me") (Serkin, 2004). Taking into account individual subjective experience, each person evaluates the meaning of stimuli and defines "meaning for oneself," which is close to the notion of sense. In group research, in contrast, the description of a group of motives is introduced and is followed by a statistical grouping of generalized characteristics of intersubjective assessment of the stimulus; this idea is close to the 
concept of signification. Thus, the notion of sense is used in studies of individual subjective experience, while the concept of signification is employed in group assessment (Serkin, 2004).

Because this article presents the results of group studies, we will use the notion of signification. Signification is understood as a unit that has denotative, operational, and affective-motivational content. This content allows us to consider signification as a unit of psychological analysis that is able to regulate activities and behavior in accordance with defined objectives, motives, and circumstances (Serkin, 2004).

\section{Research objectives}

Traditionally, the study of various phenomena in psychosemantics involves a number of stages before a researcher eventually receives the necessary results. For example, investigation of gratitude might include the study of relevant fiction, published journals, and other literature that describes the idea of gratitude; the study of everyday concepts and culturally-determined concepts, including mythological (fairy-tale) ones; and academic ideas and expert assessment (Serkin, 2004, 2008).

Taking into the account the facts mentioned above, we specified the following objectives of the study.

1. Collection of data on everyday notions of gratitude.

2. Identification of both the system of gratitude significations in the modern information and cultural environment regardless of ethnicity and the modeling of representations of the phenomenon of gratitude in people's minds.

3. Definition of the semantic space of the phenomenon of gratitude. Elicitation of the statistically-based structure of gratitude.

4. Determination of male, female, age, and ethnic peculiarities of the expression of gratitude.

\section{Method}

To achieve the research objectives, we designed our semantic differential for investigating attitudes toward gratitude. The method had two steps. The first one was to collect data on the everyday ideas of gratitude; the second one was to define semantic universals reflecting the image of gratitude and the modeling of its structure.

\section{Data collection of everyday notions of gratitude}

At this stage participants were requested to give free-form answers to the following questions: What is human gratitude? What forms might it have? What content might it have? What expresses gratitude? What is the essence of human gratitude? The answers to the questions were both separate and monosyllabic as well as in the form of mini-essays (coherent speculations).

The selection and surveying of the respondents was random. The respondents were interviewed both in person and in absentia (with the use of online interviews). At this stage the study involved 118 people aged 18 to 56 with an approximately equal ratio of male and female participants of different nationalities and from different social strata. 
From the material received (more than 12,000 words and phrases) 642 thematic word-forms were distinguished; they reflected the everyday understanding of gratitude and were different in form, content, and ways of expressing human relations. The procedure included the use of the content analysis software ContPro 6.1 , correlation analysis, and analysis of meanings.

Then the forms that were encountered more than once were selected from the 642 word-forms. Sixty word-forms that served as a basis for further study were selected. The frequency distribution of the selected word-forms is characterized as a normal distribution of data.

\section{Definition of semantic universals reflecting views of gratitude and modeling of the structure of gratitude}

With the help of the quantile-percentile selection method 18 word-forms with a maximum frequency of occurrence were selected out of the initial 60 word-forms. These 18 word-forms, first, served as an empirical basis for the design of semantic differential representations of gratitude and, second, formed a theoretical model of the structure of the notion of gratitude. The content of the variables grouped in blocks shows the presence of a particular structure and basic components of the phenomenon of gratitude: essential ("Gratitude is ..."); relational (with respect to others) (“Gratitude ..."); expressive (“Gratitude is expressed ..."); intentional (ex-

\begin{tabular}{|l|c|}
\hline Characteristics & Evaluation \\
\hline Gratitude is ... & \\
\hline experience & 12345678910 \\
\hline attitude & 12345678910 \\
\hline response & 12345678910 \\
\hline expression of warm feelings & 12345678910 \\
\hline expression of goodness & 12345678910 \\
\hline ordinary life phenomenon & 12345678910 \\
\hline acknowledgement for help & 12345678910 \\
\hline Gratitude ... & \\
\hline might be mercenary & 12345678910 \\
\hline might be insincere & 12345678910 \\
\hline might be sparing & 12345678910 \\
\hline has a goal & 12345678910 \\
\hline is addressed to particular people & 12345678910 \\
\hline Gratitude is expressed ... & \\
\hline materially & 12345678910 \\
\hline by an action & 12345678910 \\
\hline by words (is verbalized) & 12345678910 \\
\hline One ... gratitude & \\
\hline would like to receive & 12345678910 \\
\hline would like to express & 12345678910 \\
\hline can measure & 12345678910 \\
\hline Your gender & \\
\hline Your age & \\
\hline Nationality & \\
\hline
\end{tabular}

Here is a list of various features and statements that describe the phenomenon of human gratitude.

Evaluate different characteristics of this phenomenon using the 10-point scale. If the characteristic, in your opinion, is minimally represented, it should be given 1 point, if it is represented to the maximum, it should be given 10 points.

The rest of the evaluation also expresses your opinion of the representation of a particular characteristic. It is requested that you circle the corresponding evaluation. Please, be attentive and fill in all the lines. Thank you!

Figure 1. Survey for evaluating the characteristics of the semantic differential of gratitude and their representations 
pressing intention or direction) ("One ... gratitude”). The elaborated semantic differential (Figure 1) was used to define the semantic space of gratitude, to investigate its statistically-determined structure, and to define peculiarities of attitudes toward gratitude in different gender, age, and ethnic groups. At the next stage of the research this model was tested empirically.

At this stage the study involved 206 people. The data were collected by in-person interviews as well as with the use of the Internet. After the elimination of respondents because of incorrect completion of the survey as well as of representatives of those nationalities the quantity sample of which did not allow including them in statistical calculations, the total sample size was 184 people. The study involved citizens of the Russian Federation, Belarus, Kazakhstan, Tajikistan, Israel, Australia, Canada, and the United Kingdom who identified themselves as representatives of one of the nationalities (Table 1).

Table 1. Nationality and age indicators of the sample

\begin{tabular}{|c|c|c|c|c|c|}
\hline Nationality & Sex & $\begin{array}{l}\text { Age } 18 \\
\text { (youth) }\end{array}$ & $\begin{array}{c}\text { Age 19-25 } \\
\text { (adulthood) }\end{array}$ & $\begin{array}{l}\text { Age 26-56 } \\
\text { (maturity) }\end{array}$ & Total \\
\hline \multirow{2}{*}{ Russian } & Male & 12 & 7 & 47 & \multirow{2}{*}{146} \\
\hline & Female & 36 & 17 & 27 & \\
\hline \multirow{2}{*}{ Tatars } & Male & 1 & - & 1 & \multirow{2}{*}{10} \\
\hline & Female & 2 & - & 6 & \\
\hline \multirow{2}{*}{ Ukrainians } & Male & 1 & 1 & 4 & \multirow{2}{*}{9} \\
\hline & Female & - & 1 & 2 & \\
\hline \multirow{2}{*}{ Jews } & Male & - & - & 14 & \multirow{2}{*}{19} \\
\hline & Female & - & - & 5 & \\
\hline & $\Sigma$ & 52 & 26 & 106 & 184 \\
\hline
\end{tabular}

\section{Results}

Analysis of the normality of the data distribution showed normal distribution of categories in each of the groups (differentiated by gender, age, nationality). Internal consistency of the differential, its reliability, and connection of the semantic categories with the assessment of the gratitude phenomenon defined by Cronbach's $\alpha$ amounted to the index $0.75 \div 0.82\left(\chi^{2}=64.72, p<001\right)$ (the norm is $\alpha=0.65$ ), which indicates good reliability of the method and allowed us to use this method for the investigation of gratitude (Stolin, Bodalev, \& Avanesov, 2002). $\Theta$-reliability of the differential was 0.72 , which also proves its reliability with respect to the diagnostic semantics of gratitude (Stolin, Bodalev, \& Avanesov, 2002). Verification of the representativeness of the sample by the splitting method (even-odd) followed by the test of differences by means of Student's $t$-test (for all 18 universals) showed no difference (by the criterion of sex, age, ethnicity); this result allowed us to extrapolate the results of the sample survey to a large-scale general population (Stolin, Bodalev, \& Avanesov, 2002). 


\section{Elaboration of the semantic space of gratitude and its statistically-based structure}

The model verification was carried out by the factorization method (the method of principal components, a Varimax rotation), and a factor structure was obtained (Tables 2 and 3). The percentage of factor-structure stability was 59\%; the norm was $51 \%$ (Nasledov, 2004/2012). The stability of individual factors was confirmed by the Lewandowskiy method (Lewandowskiy, 1980).

Table 2. Factor structure of the phenomenon of gratitude and its basic components

\begin{tabular}{|c|c|c|c|c|}
\hline \multirow{2}{*}{ Characteristics } & \multicolumn{4}{|c|}{ Factors } \\
\hline & 1 & 2 & 3 & 4 \\
\hline Would like to receive & 0.72 & & & \\
\hline Ordinary-life phenomenon & 0.63 & & & \\
\hline Response & 0.57 & & & \\
\hline Acknowledgement for help & 0.49 & & & 0.45 \\
\hline Might be insincere & & 0.90 & & \\
\hline Might be forehanded & & 0.89 & & \\
\hline Might be mercenary & & 0.85 & & \\
\hline Has a goal & 0.35 & 0.54 & & \\
\hline Expressed materially & & 0.42 & & 0.39 \\
\hline Expression of goodness & & & 0.82 & \\
\hline Expression of warm feelings & & & 0.81 & \\
\hline Attitude & & & 0.65 & \\
\hline Expressed by an action & & & & 0.75 \\
\hline Expressed by words (is verbalized) & & & & 0.66 \\
\hline Would like to express & 0.48 & & & 0.51 \\
\hline Prp.Total & 0.13 & 0.20 & 0.13 & 0.13 \\
\hline Expl.Variance & 2.00 & 2.95 & 2.00 & 1.99 \\
\hline
\end{tabular}

Table 3. Verification of the stability of the factors by means of regression analysis

\begin{tabular}{ccccc}
\hline \multirow{2}{*}{ Factors } & \multicolumn{4}{c}{ Parameters } \\
\cline { 2 - 5 } & $R^{2}$ & $p$ & $F(1 ; \mathbf{1 5})$ & $p$ \\
\hline 1 & 0.37 & $<0.005$ & 10.71 & $<0.005$ \\
2 & 0.38 & $<0.005$ & 11.70 & $<0.005$ \\
3 & 0.42 & $<0.03$ & 12.35 & $<0.03$ \\
4 & 0.52 & $<0.0007$ & 18.15 & $<0.0007$ \\
\hline
\end{tabular}




\section{Identification of gender, age, and ethnic peculiarities of expressing gratitude}

To identify these features the procedure of comparison of individual factor ratings by Student's $t$-test (the values of each factor for each subject) was chosen (Nasledov, 2004/2012). These ratings were obtained during the elaboration of the factor structure discussed previously. The comparison of factor ratings made it possible to determine the quantitative and qualitative expression of each component. It is important to note that in the unipolar factor structure a positive value indicates an intensive expression of quality, while a negative value indicates a less intense expression of quality, but, nevertheless, the quality is present.

Among gender features the difference between the men and the women in the relational and essential components may be noted (Table 4).

Table 4. Differences between the men and the women in the components of gratitude

\begin{tabular}{|c|c|c|c|c|c|}
\hline \multirow{2}{*}{ Components } & \multicolumn{2}{|c|}{ Mean } & \multirow{2}{*}{$t$} & \multirow{2}{*}{$d f$} & \multirow[b]{2}{*}{$p$} \\
\hline & Men & Women & & & \\
\hline Relational & 0.20 & -0.16 & 2.50 & 183 & 0.01 \\
\hline Essential & -0.26 & 0.21 & -3.25 & 183 & 0.001 \\
\hline
\end{tabular}

Age differences are shown in Table 5 (age gradation corresponds to the gradation by E. Erickson).

Table 5. Age differences in the components of gratitude

\begin{tabular}{|c|c|c|c|c|c|}
\hline \multirow{2}{*}{ Components } & \multicolumn{2}{|c|}{ Mean } & \multirow{2}{*}{$t$} & \multirow{2}{*}{$d f$} & \multirow{2}{*}{$p$} \\
\hline & Age 18 (youth) & Age 19-25 (adulthood) & & & \\
\hline Intentional & 0.28 & -0.11 & 2.09 & 76 & 0.04 \\
\hline \multirow{2}{*}{ Components } & \multicolumn{2}{|c|}{ Mean } & \multirow{2}{*}{$t$} & \multirow{2}{*}{$d f$} & \multirow{2}{*}{$p$} \\
\hline & 18 (youth) & 26-56 (maturity) & & & \\
\hline Intentional & 0.28 & -0.05 & 2.04 & 156 & 0.04 \\
\hline Essential & 0.26 & -0.23 & 2.92 & 156 & 0.004 \\
\hline \multirow{2}{*}{ Components } & \multicolumn{2}{|c|}{ Mean } & \multirow{2}{*}{$t$} & \multirow{2}{*}{$d f$} & \multirow{2}{*}{$p$} \\
\hline & 19-25 (adulthood) & 26-56 (maturity) & & & \\
\hline Essential & 0.32 & -0.23 & 2.49 & 130 & 0.01 \\
\hline
\end{tabular}

Differences in the evaluation of gratitude by the criterion of nationality were not found (Table 6). 
Table 6. National differences in the components of gratitude

\begin{tabular}{|c|c|c|c|c|c|}
\hline \multirow{2}{*}{ Components } & \multicolumn{2}{|c|}{ Mean } & \multirow{2}{*}{$t$} & \multirow{2}{*}{$d f$} & \multirow{2}{*}{$p$} \\
\hline & Russians & Tatars & & & \\
\hline Intentional & 0.03 & 0.16 & -0.38 & 155 & 0.71 \\
\hline Relational & 0.01 & -0.17 & 0.56 & 155 & 0.58 \\
\hline Essential & 0.01 & 0.22 & -0.72 & 155 & 0.47 \\
\hline Expressive & -0.11 & 0.48 & -1.87 & 155 & 0.08 \\
\hline \multirow[b]{2}{*}{ Components } & \multicolumn{2}{|c|}{ Mean } & \multirow[b]{2}{*}{$t$} & \multirow[b]{2}{*}{$d f$} & \multirow[b]{2}{*}{$p$} \\
\hline & Russians & Ukrainians & & & \\
\hline Intentional & 0.03 & 0.06 & -0.07 & 154 & 0.95 \\
\hline Relational & 0.01 & -0.41 & 1.25 & 154 & 0.21 \\
\hline Essential & 0.01 & 0.30 & -0.93 & 154 & 0.35 \\
\hline Expressive & -0.11 & -0.49 & 1.08 & 154 & 0.28 \\
\hline \multirow[b]{2}{*}{ Components } & \multicolumn{2}{|c|}{ Mean } & \multirow[b]{2}{*}{$t$} & \multirow[b]{2}{*}{$d f$} & \multirow[b]{2}{*}{$p$} \\
\hline & Russians & Jews & & & \\
\hline Intentional & 0.03 & -0.11 & 0.6 & 164 & 0.55 \\
\hline Relational & 0.01 & 0.31 & -1.3 & 164 & 0.19 \\
\hline Essential & 0.01 & -0.48 & 1.20 & 164 & 0.23 \\
\hline Expressive & -0.11 & 0.71 & 1.16 & 164 & 0.25 \\
\hline \multirow[b]{2}{*}{ Components } & \multicolumn{2}{|c|}{ Mean } & \multirow[b]{2}{*}{$t$} & \multirow[b]{2}{*}{$d f$} & \multirow[b]{2}{*}{$p$} \\
\hline & Tatars & Ukrainians & & & \\
\hline Intentional & 0.16 & 0.06 & 0.20 & 17 & 0.84 \\
\hline Relational & -0.17 & -0.41 & 0.41 & 17 & 0.69 \\
\hline Essential & 0.22 & 0.30 & -0.20 & 17 & 0.84 \\
\hline Expressive & 0.48 & -0.49 & 2.16 & 17 & 0.18 \\
\hline \multirow{2}{*}{ Components } & \multicolumn{2}{|c|}{ Mean } & \multirow{2}{*}{$t$} & \multirow{2}{*}{$d f$} & \multirow{2}{*}{$p$} \\
\hline & Tatars & Jews & & & \\
\hline Intentional & 0.16 & -0.11 & 0.80 & 27 & 0.43 \\
\hline Relational & -0.17 & 0.31 & -1.10 & 27 & 0.28 \\
\hline Essential & 0.22 & -0.48 & 1.34 & 27 & 0.19 \\
\hline Expressive & 0.48 & 0.71 & -0.73 & 27 & 0.47 \\
\hline \multirow{2}{*}{ Components } & \multicolumn{2}{|c|}{ Mean } & \multirow{2}{*}{$t$} & & \\
\hline & Jews & Ukrainians & & $d f$ & $p$ \\
\hline Intentional & -0.11 & 0.06 & 0.41 & 26 & 0.68 \\
\hline Relational & 0.31 & -0.41 & -1.58 & 26 & 0.13 \\
\hline Essential & -0.48 & 0.30 & 1.38 & 26 & 0.18 \\
\hline Expressive & 0.71 & -0.49 & -2.08 & 26 & 0.10 \\
\hline
\end{tabular}




\section{Discussion}

The content interpretation of the factor-analysis results (Table 2) showed the following results.

The first unipolar factor. The main contradiction described in the space of this factor is the desire to receive gratitude from others (society) or the desire to give it back; these desires reflect the social orientation of the individual. Lomov (1984) notes that the orientation of a person is a system-forming function of the person, which manifests itself in the whole system of mental characteristics and conditions of the person: needs, interests, aptitudes, motivational sphere, value orientations, ideals, beliefs, abilities, talents, character, will, and intellectual and emotional features. That is why this factor is called the intentional component (from the Latin: intentio - value, content, desire, intention, purpose): it reflects the expectations and aspirations of the individual. In the space of the factor we see that a heavy load is carried by the desire to receive gratitude from others; however, the factor of unipolarity makes such a desire not dominant but balanced by opposing or neutral characteristics, so the person's behavior as described by this factor will be determined by the dominant individual motivations.

The second unipolar factor. The main content of this factor is the perception of the sociocultural environment as initially exploiting the individual, as insincere, full not of open human interaction but of the status and role-playing games and manipulation that determine the attitude toward gratitude. That is why this factor is called the relational component. The content of the component shows that gratitude is perceived as an exclusively material, physical act, an action, a tool for achieving specific goals. It may be insincere, selfish, sparing; it serves as a means to achieve personal goals. However, the power of expression of the instrumental understanding of gratitude is determined by individual motives too.

The third unipolar factor. This factor reflects the essential understanding of gratitude as an intangible, spiritual, ethical, and moral act of goodness and warmth toward the other. That is why this factor is called the essential component (from the Latin: essentia - the essence, the deeper meaning and significance).

The fourth unipolar factor. This factor includes variables reflecting the understanding of the form in which gratitude should be expressed. That is why this factor is called the expressive component. The variables show that gratitude can be expressed by an act, in words, in any material form and manifestation. In addition, the factor indicates that gratitude can act as a form of need ("It would like to express") and is a manifestation of the support and strengthening of social bonds that are expressed in the form of action in response to another's help.

We see that the elaborated structure of gratitude contains some contradictions. The intentional and relational components are connected to the apparently selfish understanding of human gratitude, which is to obtain something for oneself, to use gratitude as a tool to achieve one's personal goals. The essential component, on the contrary, describes deeply humanized behavior: a kind, gentle, cordial, heartwarming attitude toward the other. The expressive component remains relatively neutral.

Regression analysis of the factors allowed us to clarify the interaction of the components of gratitude. The mutual regression relationship of the intentional and 
relational components $\left(R^{2}=0.38, p<0.007 ; F(1 ; 15)=10.70, p<0.007\right)$ shows that if people tend to receive gratitude from others, they perceive gratitude as a manipulative, selfish, insincere act to a large extent, and vice versa.

The mutual regression relationship of the essential and intentional components $\left(R^{2}=0.42, p<0.03 ; F(1 ; 15)=12.35, p<0.03\right)$ shows that if people have a humanistic understanding of gratitude, they are more willing to express gratitude to the other, and vice versa.

In other words, having a mercenary, egotistical, or spiritually humanized understanding of gratitude may depend on a person's orientation-toward envy, jealousy, greed, lust for power, selfishness, kindness, humility, tolerance, collectivism.

Analysis of the discovered gender and age differences in expressing gratitude shows the following. The men had a more selfish, instrumental understanding (the relational component) of gratitude, while among the women humanistic representations (the essential component) were revealed to a greater extent (Table 4).

In the representatives of the younger generation (youth) romantic and noble ideas of gratitude dominated. They were oriented toward collectivist values, were ready to express heartwarming feelings and kindness to others and to be unselfish, but they expected a similar attitude to be shown toward themselves (Table 5).

Compared with the youth, the young adults (adulthood) expected to receive gratitude less and were less willing to express it. They considered gratitude as a natural phenomenon of life to a lesser extent; they were more selfish, not oriented toward humanistic, collectivist values. In other words, with age noble and romantic motives are replaced by a more expressed social realism. Such an assessment by the respondents in this category may be the result of the experience of receiving benefits previously unavailable through the act of expressing gratitude-for example, in the form of gifts, souvenirs, or services. However, compared with the mature generation, young adults continued to maintain remnant romantic notions about gratitude. They were oriented toward collectivist values and were ready to express warm feelings and kindness to others.

The older adults (maturity) reflected their longer life path and experience with respect to gratitude. They were not oriented toward collectivist values, and their humanistic assessment of gratitude was significantly reduced.

Differences in the evaluation of gratitude by the criterion of nationality were not found (Table 6). With respect to the research results there is a contradiction relating to the understanding of gratitude as a characteristic of national consciousness/mentality, as a cultural phenomenon defined by national and historical features (Borzheeva, 2008). Apparently, the lack of differences in the degree of manifestation of the components of the psychosemantic structure of gratitude can be explained by the peculiarities of expressing gratitude in different cultures. As Mosejko (2014) states, conventional forms of expressing gratitude and the response to it in the English and Russian languages have largely similar semantics and pragmatics. One can speak about differences in the contexts of realizing gratitude and its interactive models - that is, despite the similarity regarding "why" and "how" gratitude is expressed in the two languages, a significant difference relates to the "who," "whom," "where," and "what for" thanks in these cultures. 


\section{Conclusions}

1. This study allowed us to distinguish the content and structure of the semantic space of gratitude and to single out its components: intentional, relational, essential, and expressive. These components are present in the representatives of all the nationalities who participated in the study.

2. A direct link between nationality (ethnicity) and manifestations of and ideas about gratitude was not found.

3. Age and gender significantly influenced the idea of gratitude and its manifestations. The women in the study were more likely than the men to reflect humanistic, collectivist ideas of gratitude. Among representatives of the younger generation (youth) romantic and noble ideas of gratitude dominated. These romantic notions were replaced with realistic ones among the young and mature adults. Although the young adults (adulthood) shared some romantic notions, these ideas disappeared among the older adults (maturity).

4. In general, a mercenary, egotistical, or spiritually humanized understanding of gratitude depends on the orientation of the individual.

\section{References}

Agaev, H. F. (2013). Etnicheskiy religiozniy ekstremizm na Severnom kavkaze kak ugroza natsional'noy bezopasnosti Rossii [Ethical and religious extremism in the Northern Caucasus as a threat to the national safety of the Russian Federation]. Etnosotsium i Mezhnatsionalnaya Kultura [Ethno-Socium and International Culture], 9(63), 155-162.

Bajer, E. S. (2014). Natsionalniy kharakter anglichan [The national character of Englishmen]. In O. M. Barbakov \& U. A. Zobnin (Eds.), Matematicheskie metody i modeli v upravlenii, ekonomike i sotsiologii. Sbornik nauchnykh trudov [Mathematic methods and models in management, economics and sociology. Proceedings] (pp. 14-17). Tyumen, Russia: Tyumen State Oil and Gas University.

Belyakova, I. E., \& Grigoryan, S. G. (2010). Predstavleniya o natsionalnom kharaktere amerikantsa (na materiale romana F. S. Fitsdzheralda "Velikiy Getsbi") [Ideas about American national character (based on the novel by F. Scott Fitzgerald "The Great Gatsby"]. In L. G. Fedyuchenko (Ed.), Tekst i diskurs: Problemy analiza i interpretatsii. Sbornik nauchnykh statey [Texts and discourse. Proceedings]. (pp. 151-154). Tyumen, Russia: Ministry of Education and Science, Russian Federation; Tyumen State University.

Borzheeva, M. A. (2008). Blagodarnost kak forma kulturnoj otzyvchivosti cheloveka: K postanovke problemy [Gratitude as a form of person's cultural responsiveness. Stating the problem]. Almanah Sovremennoj Nauki i Obrazovanija [Almanac of Contemporary Science and Education], 6(2), 39. Retrieved from www.gramota.net/materials/1/2008/6-2/9.html

Bryanskaya, T. I. (2011). Etnokulturnye osobennosti kitayskogo seksizma [Ethno cultural characteristics of the Chinese sexism]. Oykumena. Regionovedcheskie Issledovaniya [Oykumena. Research in Religious Studies], 2, 104-110.

Erokhin, I. Yu. (2013). Kratkij jekskurs istorii i teorii nacionalizma [A brief review of the history and theory of nationalism]. Moscow: Knizhnyj Perekrestok.

Klimenko, L. V. (2011). Etnokulturnye osobennosti samosoznaniya naseleniya yuzhnogo federalnogo okruga [Ethno cultural characteristics of the self-consciousness of the population of the Southern Federal District]. European Social Science Journal, 10(13), 303-313. 
Lewandowskiy, N. G. (1980). O korrektnosti primeneniya faktornogo analiza i o kriteriyakh faktorizatsii [Correct use of the factor analysis and the criteria of factorization]. Voprosy Psihologii [Issues in Psychology], 5, 138-142. Retrieved from http://voppsy.ru/ issues/1980/805/805138.htm.

Lomov, B. F. (1984). Metodologicheskie i teoreticheskie problemy psikhologii [Methodological and theoretical problems of psychology]. Moscow: Nauka.

Mosejko, A. A. (2014). Jetiketnaja model blagodarnosti v anglijskoj i russkoj lingvokulturah. Filologicheskie nauki [Etiquette model of gratitude in the English and Russian linguacultures. Philological sciences]. Voprosy Teorii i Praktiki [issues in Theory and practice], 11(1), 141-144. Retrieved from www.gramota.net/materials/2/2014/11-1/39.html

Muchkaev, E. V. (2012). Etnokulturnye osobennosti Kalmykii v svete orientalizma [Ethno cultural characteristics of Kalmykia throught the perspective of orientalism]. Etnosotsium $i$ Mezhnatsionalnaya Kultura [Ethno-Socium and International Culture], 7(49), 152-154.

Nadya, T. (2011). Strategii konstruirovaniya identichnosti v musul'manskom hip-hope. Raznostoronniy analiz tvorchestva nemetskogo repera Sahiry [Strategies of building identity in musical hip-hop. Versatile analysis of the creativity of the German rapper Sahir]. Pax Islamica, 1(6), 72-88.

Nasledov, A. D. (2012). Matematicheskie metody psikhologicheskogo issledovaniya. Analiz i interpretatsiya dannykh [Mathematic methods of psychological research. Analysis and interpretation of data]. Saint Petersburg: Rech. (Original work published 2004)

Perin, R. L. (2003). Psikhologiya natsionalizma [Psychology of nationalism]. Saint Petersburg: Redaktor.

Rakhmatullina, Z. A. (1999). O nekotorykh osobennostyakh natsionalnogo kharaktera bashkir [Some peculiarities of the Bashkir national character]. Belskie Prostory [Belsk Scopes], 7, $169-179$.

Ri, S. H. (2014). Etnokulturnye smyslovye osobennosti ponimaniya shchastya u russkikh i koreytsev [Ethno cultural characteristics of understanding happiness among Russians and Koreans]. Etnosotsium i Mezhnatsionalnaya Kultura [Ethno-Socium and International Culture], 9(75), 178-181.

Ryazanov, D. S. (2014). Religioznyy ekstremizm, religiozno-politicheskiy ekstremizm i religiozniy fundamentalizm: Obshchee, osobennoe, edinichnoe [Religious extremism, religious and political extremism and religious fundamentalism: Common, peculiar and unique features]. Izvestiya Irkutskogo Gosudarstvennogo Universiteta. Seriya: Politologiya. Religiovedenie [Irkutsk State University Bulletin. Series political and Religious Studies], 7, 177-184.

Sampiev, I. M. (2010). O sootnoshenii natsionalizma, tolerantnosti i demokratii [Correlation between nationalism, tolerance and democracy]. Filosofiya Prava [Philosophy of Law], 2, 37-40.

Sampiev, I. M. (2010). O sootnoshenii natsionalizma, tolerantnosti i demokratii [[Serkin, V. P. (2004). Metody psikhosemantiki [Methods of psychosemantics]. Moscow: ASPEKT-PRESS.

Serkin, V. P. (2008). Metody psikhologii subjektivnoy semantiki i psikhosemantiki: Uchebnoe posobie dlya vuzov [Methods of subjective semantics and psychosemantics. Textbook for universities]. Moscow: Izd-vo PCHELA.

Shiryakov, D. V. (2014) Religiozno-politicheskiy ekstremizm: Sliyanie i vzaimoproniknovenie religioznykh doktrin i politicheskogo ekstremizma [Religious and political extremism: Fusion of religious doctrines and political extremism]. Molodoy Uchyonyy [Young Scientist], $13,219-222$.

Stolin, A. A., Bodalev, V. V., \& Avanesov, V. S. (2002). Obshchaya psikhodiagnostika [General psychodiagnostics]. Saint Petersburg: Rech. 
Tengizova, Zh. A. (2014). Mezhnatsionalnye otnosheniya i religioznyy eks-tremizm [International relationships and religious extremism]. Teoriya i Praktika Obshchestvennogo Razvitiya [Theory and Practice of Social Development], 17, 91-93.

Zhukova, N. V. (2010). Informatsionno-kulturnaya sreda i subjekt poznaniya [Information and cultural environment and the subject of cognition]. In S. A. Minyurova (Ed.), Aktual'nye problemy psikhologii i konfliktologii: Sbornik nauchnykh statey [Urgent issues in psychology and conflictology. Proceedings]. (pp. 55-57). Ekaterinburg, Russia: Ural State Pedagogical University.

Original manuscript received October 19, 2015

Revised manuscript accepted December 12, 2015

First published online June 30, 2016 